\title{
Silver, zinc, and copper exchange in a Na-clinoptilolite and resulting effect on antibacterial activity
}

\author{
Ayben Top*, Semra Ülkü \\ Chemical Engineering Department, Faculty of Engineering, İzmir Institute of Technology, Gülbahçe Köyü, 35437 Urla, İzmir, Turkey
}

Received 17 June 2003; received in revised form 17 November 2003; accepted 3 December 2003

Available online 7 February 2004

\begin{abstract}
$\mathrm{Ag}^{+}-\mathrm{Na}^{+}, \mathrm{Zn}^{2+}-\mathrm{Na}^{+}$, and $\mathrm{Cu}^{2+}-\mathrm{Na}^{+}$equilibria for clinoptilolite-rich mineral from Gördes (Western Anatolia) were investigated at $25^{\circ} \mathrm{C}$ and $0.1 \mathrm{~N}$ total solution normality. While silver exchange was favorable over the whole concentration range, zinc and copper were partially exchanged and preferred only at low concentrations. The standard free energies of exchanges for $\mathrm{Ag}^{+}-\mathrm{Na}^{+}, \mathrm{Zn}^{2+}-\mathrm{Na}^{+}$, and $\mathrm{Cu}^{2+}-\mathrm{Na}^{+}$pairs were found as $-6.0,2.03$, and $3.09 \mathrm{~kJ} /$ equiv., respectively. From these values, selectivity sequence was determined as $\mathrm{Ag}^{+}>\mathrm{Na}^{+}>\mathrm{Zn}^{2+}>\mathrm{Cu}^{2+}$. Antibacterial activities of the exchanged samples were measured as a function of exchange level against Pseudomonas aeruginosa and Escherichia coli. Considering the selectivity sequence of the clinoptilolite and antibacterial activity results, Ag-clinoptilolite seemed to be promising antibacterial material.
\end{abstract}

(C) 2003 Elsevier B.V. All rights reserved.

Keywords: Clinoptilolite; Cation exchange; Silver; Zinc; Copper; Antibacterial activity

\section{Introduction}

Cation exchange is one of the outstanding properties of the zeolites. Utilization of the natural zeolites as cation exchangers in water treatment has increasing interest due to their availability and low cost. Most of the studies in this area are concentrated on the use of clinoptilolite in the removal of ammonium ions related to its significant selectivity (Klieve and Semmens, 1980; Jama and Yücel, 1989; Langella et al., 2000). Also, there exist works concerned with the removal of

\footnotetext{
* Corresponding author. Fax: +90-232-498-63-55.

E-mail addresses: aybentop@iyte.edu.tr (A. Top), semraulku@iyte.edu.tr (S. Ülkü).
}

heavy metals (Semmens and Seyfard, 1978; Semmens and Martin, 1988; Zamzow and Murphy, 1992; Kesraoui-Ouki et al., 1993; Zamzow and Schultze, 1995; Langella et al., 2000). However, cation exchange is not only involved in a direct application mainly in water treatment but has a significant value as a tailoring process prior to the other applications. For example cation exchange with protons and different cations was used to increase adsorption capacity of the clinoptilolite for the certain molecules such as $\mathrm{O}_{2}$ and $\mathrm{N}_{2}$ (Arcoya et al., 1996). Similarly, silver zeolites were proposed to remove radioactive $\mathrm{I}_{2}$ from nuclear wastes and $\mathrm{Cd}-$ clinoptilolite was reported to be the most active, selective, and stable catalyst for the hydration of acetylene to acetaldehyde (Czaran et al., 1989; Onyestyák and Kalló, 1995). 
It has been known that among metallic elements, heavy metals such as silver, zinc, copper, mercury, tin, lead, bismuth, cadmium, chromium, and thallium possess antibacterial properties and the exchange with these metals imparts antibacterial activity to the zeolites (Niira et al., 1990). There are several studies concerned with the use of synthetic and natural zeolites: A, X, Y, Z, and clinoptilolite supporting metal ions ( $\mathrm{Ag}, \mathrm{Cu}, \mathrm{Zn}, \mathrm{Hg}, \mathrm{Sn}, \mathrm{Pb}, \mathrm{Bi}, \mathrm{Cd}, \mathrm{Cr}, \mathrm{Ti})$ as bactericides for water disinfection as it is cited by Rivera-Garza et al. (2000). In the industry, the Japanese product Zeomic, which is known as silverexchanged synthetic Zeolite A, has been used as a sterilizing and antibacterial agent in paper, plastic, paint, ceramics, and almost everything else that people touch or come into contact with in their daily lives (Mumpton, 2000). Recently, Mexican silver clinoptilolite-heulandite mineral was reported to eliminate the pathogenic microorganisms, Escherichia coli and $S$. faecalis from water, suggesting further studies in this field (Rivera-Garza et al., 2000). However, it is well known that variations in the purity and composition, and the existence of some impurities in these naturally occurring materials are directly reflected to their cation exchange behavior as well as the other properties affected by cation exchange.

In the scope of this study, $\mathrm{Ag}^{+}, \mathrm{Zn}^{2+}$, and $\mathrm{Cu}^{2+}$ exchange properties of the Na-form of Gördes (Turkey) clinoptilolite were investigated considering utilization of the exchanged forms as an antibacterial material. The antibacterial activities of the exchanged samples were determined against Pseudomonas aeruginosa and E. coli to estimate its role in the suppression of the development and proliferation the microorganisms.

\section{Experimental}

In the first part of the study, the clinoptilolite-rich mineral from Gördes (Western Anatolia) was characterized by using Fourier transform infrared spectroscopy (FTIR), X-ray diffraction (XRD), scanning electron microscopy (SEM) and thermal analysis techniques. IR spectrum of the sample was obtained using a Shimadzu FTIR-8201 model Fourier transformed infra-red spectrometer. XRD pattern of the sample was determined using a Philips Xpert XRA-
480 Model X-ray diffractometer and its morphology was studied by using a Philips XL30S model scanning electron microscope. Thermogravimetric (TG) analysis was performed using a Shimadzu TGA-51/51H, type instrument.

In the IR spectrum of the sample fundamental vibrations of a typical zeolite were obtained. XRD peaks of the sample were found to be in good agreement with the ones given by the 25-1349 JCPDS card belonging to clinoptilolite although some extra peaks corresponding to heulandite (24-0182) were also observed. It was also revealed by the SEM picture of the sample, in which classical clinoptilolite-heulandite family of zeolite crystals was observed. In addition to zeolitic phase, quartz, cristobalite, and K-feldspar were detected in the $\mathrm{X}$ ray diffraction patterns. The heulandite-clinoptilolite content of the sample (in wt.\%) was estimated as $80 \%$ using dolomite as an internal standard. Continuous TG curve and the absence of a sharp peak in the corresponding DTG curve, which indicates the transformation of heulandite-to-heulandite B at about 280 ${ }^{\circ} \mathrm{C}$, confirmed that the major constituent of the sample is clinoptilolite rather than heulandite (Gotardi and Galli, 1985).

After grinding and sieving, the 38-75 $\mu \mathrm{m}(400-$ 200 mesh) portion was used in the ion exchange equilibrium studies. Homoionic Na-clinoptilolite was prepared by stirring $125 \mathrm{~g}$ of sample and $1250 \mathrm{ml}$ of $1 \mathrm{~N} \mathrm{NaCl}$ solution at $500 \mathrm{rpm}$ in a $2000-\mathrm{ml}$ closed beaker placed in a constant temperature water bath maintained at $60{ }^{\circ} \mathrm{C}$ for one week. $\mathrm{NaCl}$ solution was replaced every day. This clinoptilolite sample was washed with deionized water several times and dried in oven at $110{ }^{\circ} \mathrm{C}$. Then, it was placed over saturated $\mathrm{NH}_{4} \mathrm{Cl}$ solution ( $\approx 80 \%$ relative humidity) prior to the chemical analyses and ion exchange experiments. Chemical compositions of the samples were determined using a Varian ICP 96 Inductively Coupled Plasma Atomic Emission Spectrometer (ICP-AES) subsequent to lithium tetraborate fusion and dissolution in 1.6 $\mathrm{M} \mathrm{HNO}_{3}$ solution and are given in Table 1. Water contents were obtained from the TG analyses. In the binary ion exchange studies, $\mathrm{NaNO}_{3}, \mathrm{AgNO}_{3}$, $\mathrm{Zn}\left(\mathrm{NO}_{3}\right)_{2} \cdot 5 \mathrm{H}_{2} \mathrm{O}$, and $\mathrm{Cu}\left(\mathrm{NO}_{3}\right)_{2} \cdot 2.5 \mathrm{H}_{2} \mathrm{O}$ were used as cation sources. The experiments were conducted by treating Na-clinoptilolite with a series of solutions at $0.1 \mathrm{~N}$ containing different proportions of two com- 
Table 1

Chemical composition of the original and Na-form of the Gördes clinoptilolite mineral

\begin{tabular}{|c|c|c|}
\hline Species (w/w, \%) & Natural-CLI & $\mathrm{Na}-\mathrm{CLI}$ \\
\hline $\mathrm{SiO}_{2}$ & 66.36 & 68.36 \\
\hline $\mathrm{Al}_{2} \mathrm{O}_{3}$ & 11.36 & 11.73 \\
\hline $\mathrm{Fe}_{2} \mathrm{O}_{3}$ & 1.227 & 0.694 \\
\hline $\mathrm{K}_{2} \mathrm{O}$ & 3.844 & 1.959 \\
\hline $\mathrm{Na}_{2} \mathrm{O}$ & 0.998 & 5.810 \\
\hline $\mathrm{CaO}$ & 2.344 & 0.169 \\
\hline $\mathrm{MgO}$ & 0.420 & 0.150 \\
\hline $\mathrm{H}_{2} \mathrm{O}$ & 14.22 & 12.09 \\
\hline Total & 100.77 & 101.31 \\
\hline$\%$ Cation balance error ${ }^{\mathrm{a}}$ & 8.397 & 1.599 \\
\hline
\end{tabular}

${ }^{\mathrm{a}}$ Cation balance error $=\left[\left(\mathrm{Al}^{3+}+\mathrm{Fe}^{3+}\right)-\left(\mathrm{Na}^{+}+\mathrm{K}^{+}+2 \mathrm{Ca}^{2+}+\right.\right.$ $\left.\left.2 \mathrm{Mg}^{2+}\right)\right] /\left[\mathrm{Al}^{3+}+\mathrm{Fe}^{3+}\right] \times 100 \%$.

peting cations in polyethylene bottles placed in a shaker at $25{ }^{\circ} \mathrm{C}$ for 2 days. The masses of clinoptilolite were varied between 0.1 and $1 \mathrm{~g}$, whereas the solution volumes were changed from 5 to $25 \mathrm{ml}$ to ensure evenly distributed data along the ion exchange isotherm. Solid and solution phases were separated by centrifuging at $4000 \mathrm{rpm}$. Initial and final concentrations of the exchanging cations and sodium were determined using the ICP-AES. Precautions were taken for the light sensitivity of silver. The $\mathrm{pH}$ of each solution was allowed to vary within its natural path. It is well known that above a certain $\mathrm{pH}$ (depending on the solubility product of metal hydroxide/oxide/carbonate as well as the concentration of the metal) precipitation occurs. The $\mathrm{pH}$ measurements showed that in our experimental conditions these limit values were not exceeded. Cation-exchanged forms of the clinoptilolite were washed with deionized water, dried and then equilibrated with water vapor over saturated $\mathrm{NH}_{4} \mathrm{Cl}$ solution prior to antibacterial activity tests.

Antibacterial activity of the exchanged forms of the clinoptilolite against $P$. aeruginosa, and $E$. coli were determined by the disk diffusion (Kirby-Bauer) method as follows: bacterial cultures were grown on Mueller-Hinton agar medium at $37{ }^{\circ} \mathrm{C}$ for overnight. One of the colonies was picked up and dissolved in 1 $\mathrm{ml}$ of distilled water; the turbidity was adjusted to McFarland no. 1 ( $\left.10^{9} \mathrm{CFU}\right)$. After placing a sterile cotton swab in the bacterial suspension, the swab was streaked in at least two directions over the surface of the Mueller-Hinton agar to obtain uniform growth.
Approximately $0.2 \mathrm{~g}$ of clinoptilolite specimen in the form of pellets with $8 \mathrm{~mm}$ in diameter was placed into the plates. The plates were incubated at $37{ }^{\circ} \mathrm{C}$ over $5 \% \mathrm{CO}_{2}$ medium and, finally, the width of inhibition zone of each sample in the plates was measured at the end of the first day.

\section{Results and discussion}

Ion exchange equilibrium isotherms were plotted in terms of the equivalent fraction of the ingoing ion in the solution $\left(A_{\mathrm{s}}\right)$ against that in the solid phase $\left(A_{\mathrm{z}}\right)$. $A_{\mathrm{s}}$ and $A_{\mathrm{z}}$ were calculated using the relations given below:

$A_{\mathrm{s}}=z_{\mathrm{A}} M_{\mathrm{A}, \mathrm{f}} / \mathrm{TN}$

$A_{\mathrm{z}}=z_{\mathrm{A}}\left(M_{\mathrm{A}, \mathrm{i}}-M_{\mathrm{A}, \mathrm{f}}\right) V /(W \cdot \mathrm{CEC})$

where $z_{\mathrm{A}}=$ charge of the ingoing cation, $M_{\mathrm{A}, \mathrm{i}}$ and $M_{\mathrm{A}, \mathrm{f}}=$ initial and final molar concentrations of ingoing cation, respectively, $\mathrm{TN}=$ total normality $=$ $0.1 \mathrm{~N}, V=$ solution volume, $W=$ zeolite mass, and $\mathrm{CEC}=$ cation exchange capacity.

Since homoionic Na-clinoptilolite was prepared at $60{ }^{\circ} \mathrm{C}$ whereas the equilibrium studies were conducted at $25^{\circ} \mathrm{C}$, it seems reasonable to assume that potassium, calcium, and magnesium present in Na-clinoptilolite are in inaccessible ion exchange sites and do not participate in the ion exchange process at $25{ }^{\circ} \mathrm{C}$. For this reason, CEC was calculated as $1.87 \mathrm{meq} / \mathrm{g}$ corresponding to total equivalents of sodium in the Gördes clinoptilolite as proposed by Pabalan (1994).

As given in Table 1, approximately half of the potassium ions and small portions of calcium and magnesium ions remained in the homoionic Na-clinoptilolite. In the clinoptilolite structure, potassium is situated in $\mathrm{M}(3)$ site, which has the highest coordination number among all the cation sites in the unit cell. Since $\mathrm{K}^{+}$is coordinated by six framework oxygen atoms and three water molecules, the strong bonding of $\mathrm{K}^{+}$at this site may be effective in its lower exchange ability (Jama and Yücel, 1989). Cations interact with water molecules to form clusters (hydration spheres) and the characteristics of these clusters depend on the size and charge of the cation. In general, hydrated radius is inversely proportional to 


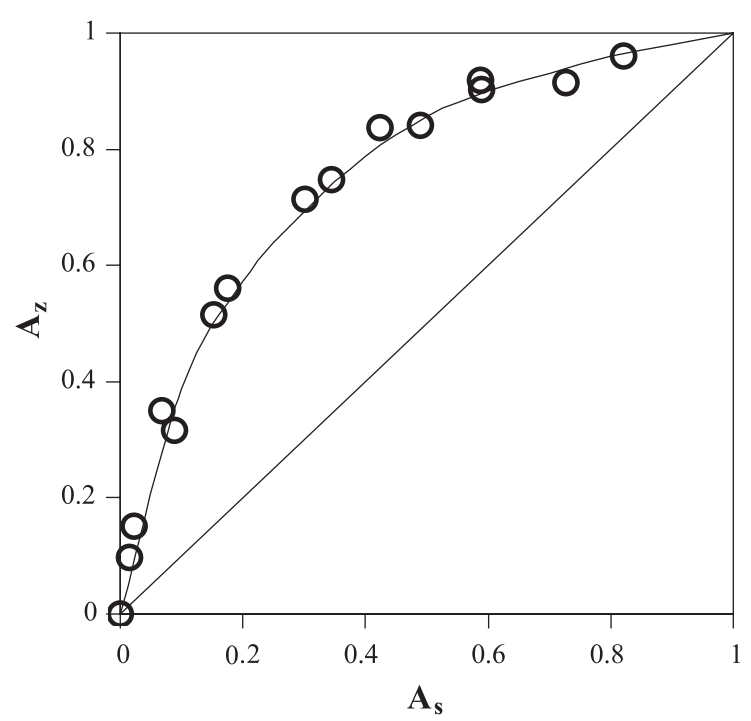

Fig. $1 . \mathrm{Ag}^{+}-\mathrm{Na}^{+}$exchange isotherm at $25{ }^{\circ} \mathrm{C}$.

cation radius, and divalent cations usually have a higher hydrated radius than monovalent cations (Palmer and Gunter, 2001). Thus, small alkaline earth cations, $\mathrm{Ca}^{2+}$ and $\mathrm{Mg}^{2+}$, cannot move easily out of the channels due to their considerably higher hydrated radii. This fact also explains why it is more difficult to remove the smaller $\mathrm{Mg}^{2+}$ ions than $\mathrm{Ca}^{2+}$ ions. (Czaran et al., 1989).

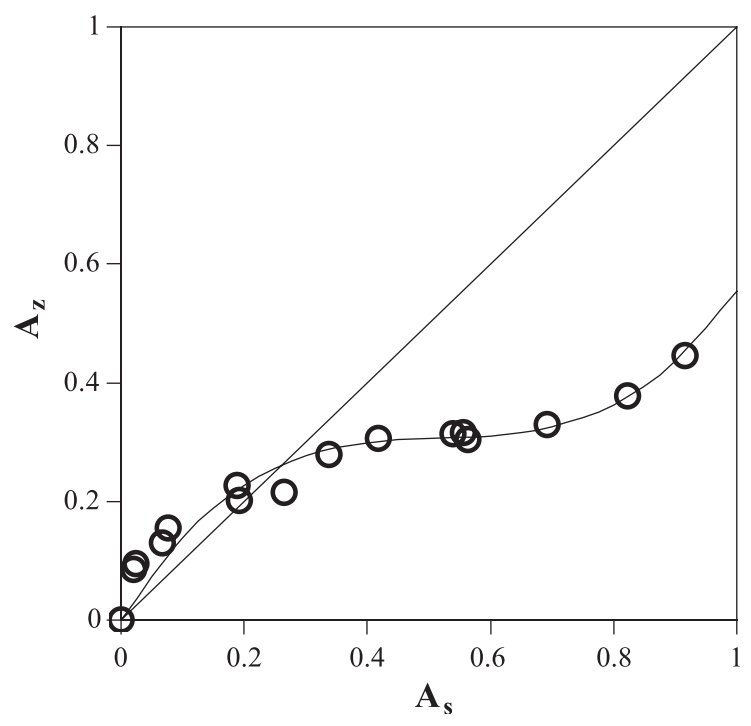

Fig. 2. $\mathrm{Zn}^{2+}-\mathrm{Na}^{+}$exchange isotherm at $25{ }^{\circ} \mathrm{C}$.
The isotherms of $\mathrm{Ag}^{+}-\mathrm{Na}^{+}, \mathrm{Zn}^{2+}-\mathrm{Na}^{+}$, and $\mathrm{Cu}^{2+}$ $\mathrm{Na}^{+}$exchanges are shown in Figs. 1-3. Silver exchange isotherm lies above the diagonal over the whole composition range, thereby indicating the considerable selectivity of clinoptilolite towards silver. On the other hand, for zinc and copper exchanges, the isotherms are above the diagonal only for low concentrations. Therefore, the preference of clinoptilolite for zinc and copper depends strongly on the concentration. While full exchange was attained for silver, partial exchanges were obtained in the case of zinc and copper.

Activity ratios of solutions were calculated by combining Pitzer model estimating mean activity coefficient in molality scale with Glueckauf extension of Guggenheim's original theory (Pitzer, 1991; Dyer et al., 1981). Since the solution densities, measured as a function of equivalent fractions of the ingoing cation, showed no significant change, the conversion between molality and molarity scales was ignored.

For each exchange, the separation factors $\left(\alpha_{\mathrm{B}}^{\mathrm{A}}\right)$ decreased with increase in the equivalent fraction of the ingoing cation in the clinoptilolite as given in Fig. 4. The values of the separation factors also showed the moderate affinity of clinoptilolite for silver. In the case of zinc and copper exchanges, unselective behavior was observed over $A_{\mathrm{s}} \approx 0.2$ whereas a modest selectivity was noticed at lower values of $A_{\mathrm{s}}$ emphasizing the dependence of the selectivity on the extent of ion

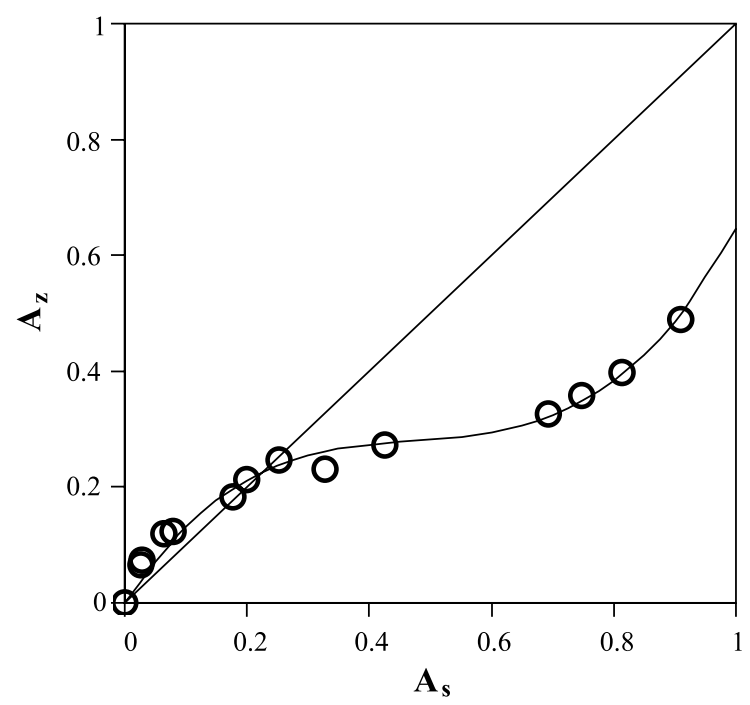

Fig. 3. $\mathrm{Cu}^{2+}-\mathrm{Na}^{+}$exchange isotherm at $25^{\circ} \mathrm{C}$. 


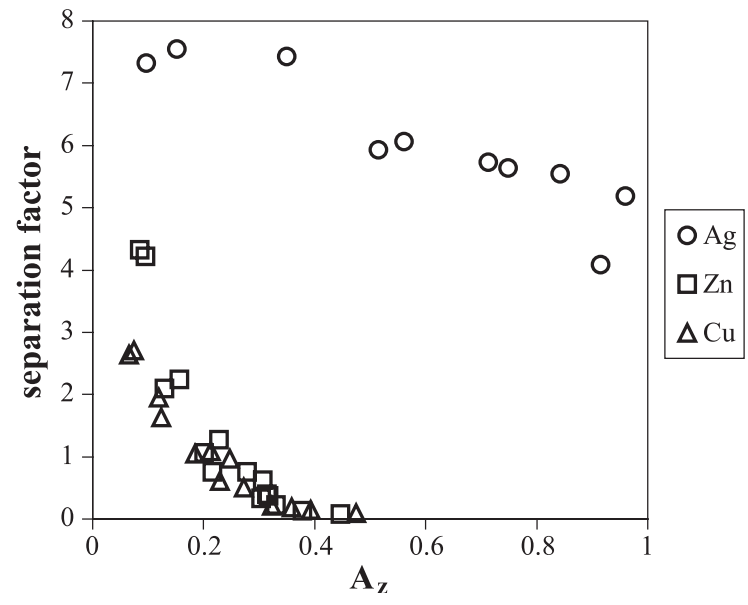

Fig. 4. Variation of separation factors with $A_{\mathrm{z}}$.

exchange. The switch in the selectivity mode of the clinoptilolite towards zinc and copper can be attributed to the change in the Coulombic repulsion energy between the cations. Naturally, cations prefer the sites possessing high potential energy in order to be more stabilized. As the number of cations incorporated into the zeolite increases, the stability of the cation in a certain site can be weakened due to the increase in intercationic repulsions. Hence, an accessible site may not host entering cations as a result of such interactions. Since Coulombic force is directly proportional to the charge of the cation, the decrease in selectivity is more significant in the case of the divalent cations.

The thermodynamic equilibrium constants, $K_{\mathrm{a}}$, calculated from the area under the curve $\ln K_{\mathrm{c}}$ vs. $A_{\mathrm{z}}$ known as Kielland plots. Since for zinc and copper, partial exchanges are involved, normalized forms of Kielland plots were used.

The calculated thermodynamic equilibrium constants, standard free energies of exchange, and maximum exchange levels are given in Table 2. Considering the Eisenmann theory, high $\mathrm{Si} / \mathrm{Al}$ ratio of clinoptilolite brings about low anionic field that gives good selectivity towards cations of lower charge, e.g. $\mathrm{Ag}^{+}$and poor selectivity towards cations of higher charge, e.g. divalent cations (Langella et al., 2000). From the data in Table 2, the selectivity sequence was obtained as $\mathrm{Ag}^{+}>\mathrm{Na}^{+}>\mathrm{Zn}^{2+}>\mathrm{Cu}^{2+}$ confirming this theory. However, favorable isotherms were obtained for $\mathrm{Pb}^{2+}-\mathrm{Na}^{+}$ and $\mathrm{Pb}^{2+}-\mathrm{NH}_{4}^{+}$exchanges of clinoptilolite as cited by Inglezakis et al. (2002), limiting the use of this theory in the interpretation of the selectivity behavior alone. Higher polarizibility and higher ionic radius of silver may be other explanations of its affinity for the clinoptilolite (Barrer, 1978). Poor selectivity of the clinoptilolite for copper may also be resulted from its high hydration energy (Semmens and Seyfard, 1978).

In the literature, there exists scant work related to the exchange equilibria of $\mathrm{Ag}^{+}-\mathrm{Na}^{+}, \mathrm{Zn}^{2+}-\mathrm{Na}^{+}$, and $\mathrm{Cu}^{2+}-\mathrm{Na}^{+}$pairs for clinoptilolite. Langella et al. (2000) determined the selectivity sequence of the Sardinian clinoptilolite as $\mathrm{Na}^{+}>\mathrm{Cu}^{2+} \cong \mathrm{Zn}^{2+}$, considering the respective standard free energy of exchange values of 2.83 and $2.71 \mathrm{~kJ} /$ equiv. for $\mathrm{Zn}^{2+}-\mathrm{Na}^{+}$and $\mathrm{Cu}^{2+}-\mathrm{Na}^{+}$pairs in the same experimental conditions. This slight difference in free energy of exchange values can be explained by the variations in the compositions of the Gördes and the Sardinian clinoptilolites. Additionally, in the current study, more experimental data is available for the low concentration region where higher selectivity of the Gördes clinoptilolite for zinc compared to copper was obtained (Fig. 4).

Antibacterial activities of the Ag-, $\mathrm{Zn}-$, and $\mathrm{Cu}-$ exchanged clinoptilolite with different exchange levels were determined by the disk diffusion method. No antibacterial action was observed for the original and Na-forms. The width of the inhibition zones of the antibacterial metal-exchanged forms as a function of the exchange level measured in the cases of two different strains, $P$. aeruginosa and $E$. coli, are given in Figs. 5 and 6, respectively. Silver-exchanged samples showed considerable superiority over the other forms, especially against $P$. aeruginosa. It was obtained that up to a certain point metal loading is essential to achieve the suppression of the microorganisms. However, it was also observed that, especially in the case of silver, high loadings usually resulted in a reduction in the antibacterial activity. Inoue and Kanzaki (1997) investigated the relationship between the oxidation state of silver and antibacterial activity by the electrochemical method and they observed no antibacterial

Table 2

Maximum exchange levels, $K_{\mathrm{a}}$, and $\Delta G^{\theta}$ values of investigated equilibria

\begin{tabular}{lllc}
\hline Cation pair & $x_{\max }$ & $K_{\mathrm{a}}$ & $\Delta G^{\theta}(\mathrm{kJ} /$ equiv. $)$ \\
\hline $\mathrm{Ag}^{+}-\mathrm{Na}^{+}$ & 1 & 11.25 & -6.00 \\
$\mathrm{Zn}^{2+}-\mathrm{Na}^{+}$ & 0.555 & 0.187 & 2.03 \\
$\mathrm{Cu}^{2+}-\mathrm{Na}^{+}$ & 0.646 & 0.083 & 3.09 \\
\hline
\end{tabular}




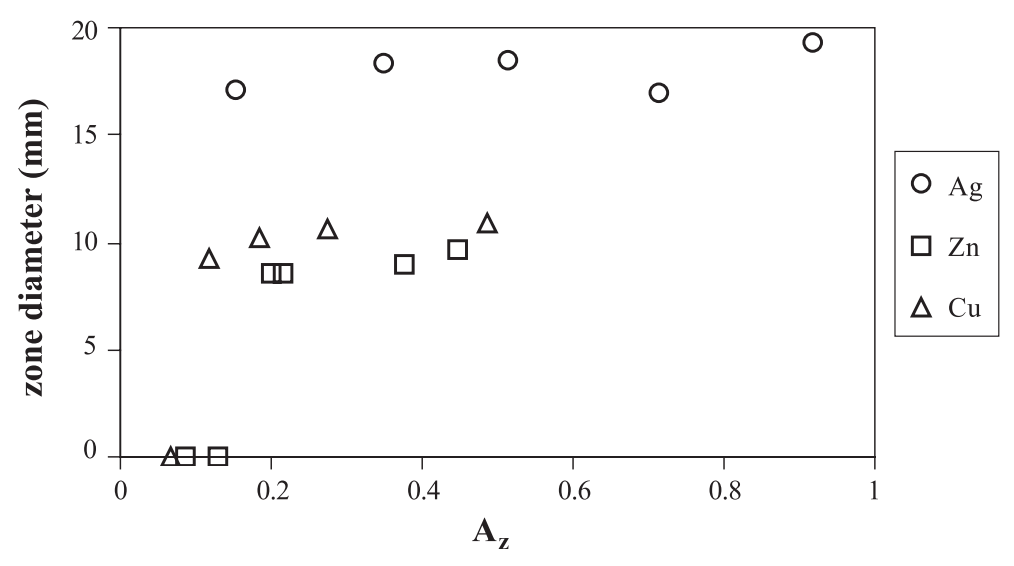

Fig. 5. Inhibition zones of the samples as a function of the exchange level against $P$. aeruginosa.

activity when the oxidation state of silver was changed from +1 to 0 . Taking account into this observation, the adverse effect may be explained by the reduction of some portion of the exchanged $\mathrm{Ag}^{+}$to $\mathrm{Ag}^{0}$ on the surface of the zeolite which may result in decrease in porosity and hence the accessibility of the exchanged $\mathrm{Ag}^{+}$ions. Additionally, for the fully silver-exchanged heulandite, the total amount of silver ions detected from $\mathrm{X}$-ray refinement was found to be significantly smaller than derived from chemical analysis, indicating part of the silver could not occupy the exchange sites. It was proposed that a portion of these disordered $\mathrm{Ag}^{+}$ions probably less tightly bound might undergo a reduction process to metallic silver (Bresciani-Pahor et al., 1981). Furthermore, in the silver-exchanged Mexican clinoptilolite-heulandite mineral, some small particles on the surface of the zeolitic material were observed. Elemental microanalyses revealed that these particles contained high concentration of silver, which was proposed to be $\mathrm{Ag}^{0}$ and this observation strengthened the explanation for the reduced antibacterial activity (Rivera-Garza et al., 2000). Therefore, it is likely that at high exchange levels, antibacterial activity of the samples may not be enhanced due to the increase in the disordered $\mathrm{Ag}^{+}$ions; indeed, it may be inhibited as a result of the reduction in the porosity.

\section{Conclusions}

$\mathrm{Ag}, \mathrm{Zn}$, and $\mathrm{Cu}$ exchange properties of the sodium form of the Gördes clinoptilolite were investigated for

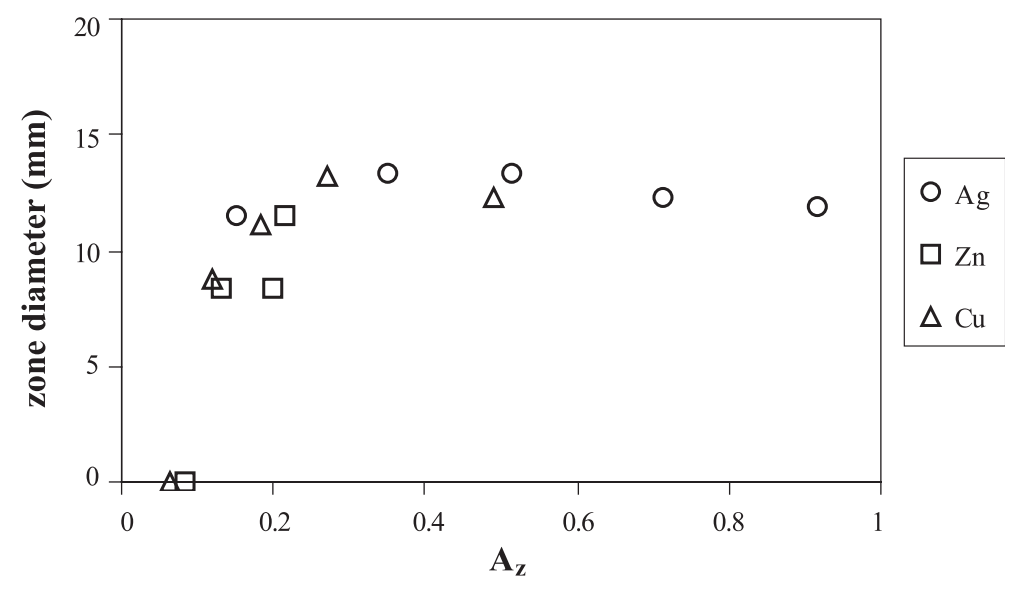

Fig. 6. Inhibition zones of the samples as a function of the exchange level against $E$. coli. 
possible utilization of the exchanged forms as an antibacterial material and the resulting effect of the exchanges on the antibacterial activity of the clinoptilolite was examined.

Na-clinoptilolite was found to be selective for silver ions over the whole concentration region, whereas it was unselective for zinc and copper ions except in low concentration regions where a modest selectivity of the clinoptilolite was observed.

The exchanged forms were tested against two different strains. It was found that the increase in metal loading did not always yield an increase in the antibacterial activity but a certain limit should be exceeded.

Consequently, Ag-clinoptilolite can be proposed as a low cost antibacterial material considering the selectivity sequence and antibacterial activity results.

\section{Acknowledgements}

The authors are grateful to Research Assistant Mert Sudağidan and Department of Biotechnology and Bioengineering for the antibacterial activity tests and to Dr. Fahri Esenli for the estimation of the zeolite content of the sample.

\section{References}

Arcoya, A., Gonzalez, J.A., Llabre, G., Seoane, X.L., Travieso, N., 1996. Role of countercations on the molecular sieve properties of a clinoptilolite. Microporous Materials 7, 1-13.

Barrer, R.M., 1978. Cation-exchange equilibria in zeolites and feldspathoids. In: Mumpton, F.A., Sand, L.B. (Eds.), Natural Zeolites: Occurrence, Properties and Use. Pergamon, New York, pp. 385-395.

Bresciani-Pahor, N., Calligaris, M., Nardin, G., Randaccio, L., 1981. Location of cations in metal ion-exchanged zeolites: Part 2. Crystal structures of a fully silver-exchanged heulandite. J.C.S. Dalton Transactions 12, 2288-2291.

Czaran, E., Papp, J., Meszaros-Kis, A., Domokos, E., 1989. Ag-ion exchange by natural mordenite and clinoptilolite. Acta Chimica Hungarica 126 (5), 673-683.

Dyer, A., Enamy, H., Townsend, R.P., 1981. The plotting and interpretation of ion-exchange isotherms in zeolite systems. Separation Science and Technology 16 (2), 173-181.

Gotardi, G., Galli, E., 1985. Natural Zeolites. Springer-Verlag, Berlin.

Inglezakis, V.J., Loizidou, M.D., Grigoropoulou, H.P., 2002. Equilibrium and kinetic ion exchange studies of $\mathrm{Pb}^{2+}, \mathrm{Cr}^{3+}, \mathrm{Fe}^{3+}$, and $\mathrm{Cu}^{2+}$ on natural clinoptilolite. Water Research 36, 2784-2792.
Inoue, Y., Kanzaki, Y., 1997. The mechanism of antibacterial activity of silver-loaded zeolite. Journal of Inorganic Biochemistry 67 $(1-4), 377$.

Jama, M.A., Yücel, H., 1989. Equilibrium studies of sodium-ammonium, potassium-ammonium, and calcium-ammonium exchanges on clinoptilolite zeolite. Separation Science and Technology 24 (15), 1393-1415.

Kesraoui-Ouki, S., Cheeseman, C.R., Perry, R., 1993. Effects of conditioning and treatment of chabazite and clinoptilolite prior to lead and cadmium removal. Environmental Science and Technology 27, 1108-1116.

Klieve, J.R., Semmens, M.J., 1980. An evaluation of pretreated natural zeolites for ammonium removal. Water Research 14, $161-168$.

Langella, A., Pansini, M., Cappelletti, P., de Gennaro, B., de Gennaro, M., Colella, C., 2000. $\mathrm{NH}_{4}^{+}, \mathrm{Cu}^{2+}, \mathrm{Zn}^{2+}, \mathrm{Cd}^{2+}$, and $\mathrm{Pb}^{2+}$ exchange for $\mathrm{Na}^{+}$in a sedimentary clinoptilolite, North Sardinia, Italy. Microporous and Mesoporous Materials 37, 337-343.

Mumpton, F.A., 2000. Natural zeolites: where have we been? Where are we going? In: Colella, C., Mumpton, F.A. (Eds.), Natural Zeolites for the Third Millenium. De Frede Editore, Napoli, pp. 19-34.

Niira, R., Yamamoto, T., Uchida, M. 1990. Antibiotic Zeolite. US Patent 4938958.

Onyestyák, G., Kalló, D., 1995. Cd-clinoptilolite as a catalyst for the hydration of acetylene to acetaldehyde. In: Ming, D.W., Mumpton, F.A. (Eds.), Natural Zeolites 93: Occurrence, Properties, Use. International Committee on Natural Zeolites, New York, pp. 437-445.

Pabalan, R.T., 1994. Thermodynamics of ion exchange between clinoptilolite and aqueous solutions of $\mathrm{Na}^{+} / \mathrm{K}^{+}$and $\mathrm{Na}^{+} / \mathrm{Ca}^{2+}$. Geochimica et Cosmochimica Acta 58 (21), 4573-4590.

Palmer, J.L., Gunter, M.E., 2001. The effects of time, temperature, and concentration on $\mathrm{Sr}^{2+}$ exchange in clinoptilolite in aqueous solutions. American Mineralogist 86, 431-437.

Pitzer, K.S., 1991. Ion interaction approach: theory and data correlation. In: Pitzer, K.S. (Ed.), Activity Coefficients in Solutions. CRC Press, Boca Raton, pp. 75-154.

Rivera-Garza, M., Olguin, M.T., Garcia-Sosa, I., Alcantara, D., Rodriguez-Fuentes, G., 2000. Silver Supported on natural mexican zeolite as an antibacterial material. Microporous and Mesoporous Materials 39, 431-444.

Semmens, M.J., Martin, W.P., 1988. The influence of pretreatment on the capacity and selectivity of clinoptilolite for metal ions. Water Research 22 (5), 537-542.

Semmens, M.J., Seyfard, M., 1978. The selectivity of clinoptilolite for certain heavy metals. In: Mumpton, F.A., Sand, L.B. (Eds.), Natural Zeolites: Occurrence, Properties and Use. Pergamon, New York, pp. 517-526.

Zamzow, M.J., Murphy, J.E., 1992. Removal of metal cations from water using zeolites. Separation Science and Technology 27 (14), 1969-1984.

Zamzow, M.J., Schultze, L.E., 1995. Treatment of acid mine drainage using natural zeolites. In: Ming, D.W., Mumpton, F.A. (Eds.), Natural Zeolites 93: Occurrence, Properties, Use. International Committee on Natural Zeolites, New York, pp. 405-413. 